\title{
FAKTOR-FAKTOR YANG BERHUBUNGAN DENGAN PENYAKIT DIABETES MELITUS TIPE 2 PADA PASIEN DI RUMAH SAKIT GRANDMED LUBUK PAKAM
}

\author{
Reno Irwanto ${ }^{1}$, Annisa Febriana Siregar², Keleng Ate Ginting ${ }^{3}$, Feberlian \\ Ndruru $^{4}$, \\ Program Studi Gizi Fakultas Kesehatan Masyarakat \\ Institut Kesehatan Medistra Lubuk Pakam \\ Jl. Sudirman No.38 Lubuk Pakam Kec. Lubuk Pakam Kab. Deli Serdang, \\ Sumatera Utara \\ Email: ireno@outlook.com
}

\begin{abstract}
Diabetes mellitus (DM) type 2 is a type of DM which is caused by the inability of the body to process glucose into the body which eventually causes an increase in glucose in the blood. Type 2 diabetes occurs because the amount of the hormone insulin is insufficient for glucose metabolism or decreased body sensitivity to the amount of blood glucose. There are many things that cause type 2 diabetes, including poor diet, lack of physical activity, obesity, heredity, increasing age and a history of type 3 diabetes (gestational). This study was conducted on 50 respondents at the Grandmed Lubuk Pakam hospital with a cross sectional study design and the respondents were selected by purposive sampling technique. The relationship factors seen in this study were age, gender, level of education, occupation, level of education, level of physical activity, smoking, obesity and diet. The results of the research obtained through the questionnaire were tested with the chi-square formula $\left(X^{2}\right)$ at the $5 \%$ real level. The results showed the distribution of respondents' occupation with $28 \%$ of respondents working as civil servants, $22 \%$ were retirees and $18 \%$ were private workers. The distribution of the respondents' physical activity consists of 3 levels, namely high, medium and low with percentage values of $26 \%, 22 \%$, and $52 \%$, respectively. The distribution of the respondents' weight group was found that $18 \%$ of the respondents were underweight, $46 \%$ were normal, and $36 \%$ were obese. The test results showed the distribution of the respondent's diet in 2 groups, namely healthy and unhealthy with the percentage of the unhealthy group $66 \%$ and $34 \%$ healthy. and the distribution of respondents' smoking levels consisted of heavy, moderate, mild and non-smoking with percentage values of $26 \%, 22 \%, 12 \%$, and $40 \%$, respectively.
\end{abstract}

\section{Keyword : diet, diabetes mellitus type 2, physical activity}




\section{PENDAHULUAN}

Diabetes melitus (DM) tipe 2 merupakan penyakit gangguan metabolik dengan karakteristik hiperglikemia, hal ini terjadi dikarenakan perilaku pola makan yang tidak benar. DM tipe 2 terjadi dengan adanya peningkatan kadar gula darah didalam tubuh. Penderita DM tipe 2 memiliki risiko terjadinya komplikasi penyakit lainnya seperti stroke, jantung, penyempitan pembuluh darah dan bahkan kanker. Komplikasi yang mungkin terjadi akibat DM tipe 2 bisa akut dan bahkan komplikasi kronik dan berkepanjangan (Decroli, 2019).

Menurut International Diabetes Federation (2019), sebanyak 463 juta orang didunia menderita diabetes dan akan meningkat hingga $51 \%$ pada tahun 2045 menjadi 700 juta penderita. Secara global IDF (2019), mencatat bahwa kawasan asia menjadi daerah dengan pertumbuhan angka diabetes yang berada diurutan ketiga dengan persentase peningkatan $74 \%$ setelah afrika dan timur tengah juga afrika utara dengan masing-masing angka peningkatan sebesar $143 \%$ dan $96 \%$.

Posisi Indonesia pada tahun 2019 berada pada rangking 7 di dunia sebagai negara penderita diabetes terbesar dengan kisaran umur penderita (20-79 tahun) dan diperkirakan akan bertahan di posisi tersebut hingga tahun 2030 (IDF, 2019). Hal ini akan dapat berakibat buruk apabila tidak ditangani dengan serius. Laporan Nasional Riset Kesehatan Dasar (Riskesdas, 2019) menunjukkan bahwa Jakarta, Yogyakarta, Kalimantan Timur dan Sulawesi Utara merupakan daerah dengan angka prevalensi penyakit diabetes tertinggi di Indonesia. Sumatera utara menjadi provinsi dengan prevalensi terbesar ketiga di pulau sumatera setelah Bangka Belitung dan Aceh.
Rumah Sakit (RS) Grandmed merupakan salah satu rumah sakit yang menerima banyak pasien DM tipe 2. DM tipe 2 termasuk dalam sepuluh penyakit terbanyak dari pasien yang berkunjung ke RS Grandmed. Hasil observasi awal yang dilakukan oleh peneliti pada bulan Desember 2020, diketahui penderita DM tipe 2 yang berkunjung sebanyak 568 orang, dan sebagian besar mengalami gangguan tidur, (Simarmata,dkk 2020)

Menurut IDF (2018), DM tipe 2 berhubungan riwayat keluarga, obesitas, pola makan yang tidak sehat, kurangnya aktifitas fisik, pertambahan usia, dan tekanan darah tinggi. Berdasarkan penyebab yang mungkin meningkatkan risiko penyakit DM tipe 2 tersebut, maka peneliti berkeinginan untuk mengetahui faktor-faktor yang berhubungan dengan kajian diabetes melittus tipe 2 di RS Grandmed.

\section{METODE PENELITIAN}

Penelitian ini merupakan penelitian analitik dengan desain crosssectional dengan pengambilan data variabel independen dan variabel dependen dilakukan dalam waktu bersamaan. Penelitian ini bersifat analitik karena akan melihat hubungan antara variabel independen dan variabel dependen. Variabel yang diteliti adalah pola makan dengan jenis kelamin yang dilakukan di RS Grandmed. Penelitian dilakukan di RS Grandmed Lubuk Pakam, Kabupaten Deli Serdang dengan tipe RS ini adalah B. Responden yang digunakan sebagai objek penelitian adalah pasien DM tipe 2 yang berobat ke RS Grandmed Lubuk Pakam. Sampel yang digunakan dalam penelitian ini adalah pasien DM tipe 2 yang memenuhi kriteria inklusi. Jumlah sampel yang digunakan adalah 50 orang responden yang didapatkan dari 125 orang dengan cara Teknik purposive sampling. Penggumpulan data dilakukan dengan 
menggunakan instrument kuisioner. Kuisioner berisikan pola makan dan aktifitas fisik. Hasil data yang diperoleh dilakukan uji dengan menggunakan rumus chisquare $\left(\mathrm{X}^{2}\right)$ pada taraf nyata $5 \%$.

\section{HASIL PENELITIAN}

Tabel 1. Distribusi pekerjaan responden DM tipe 2

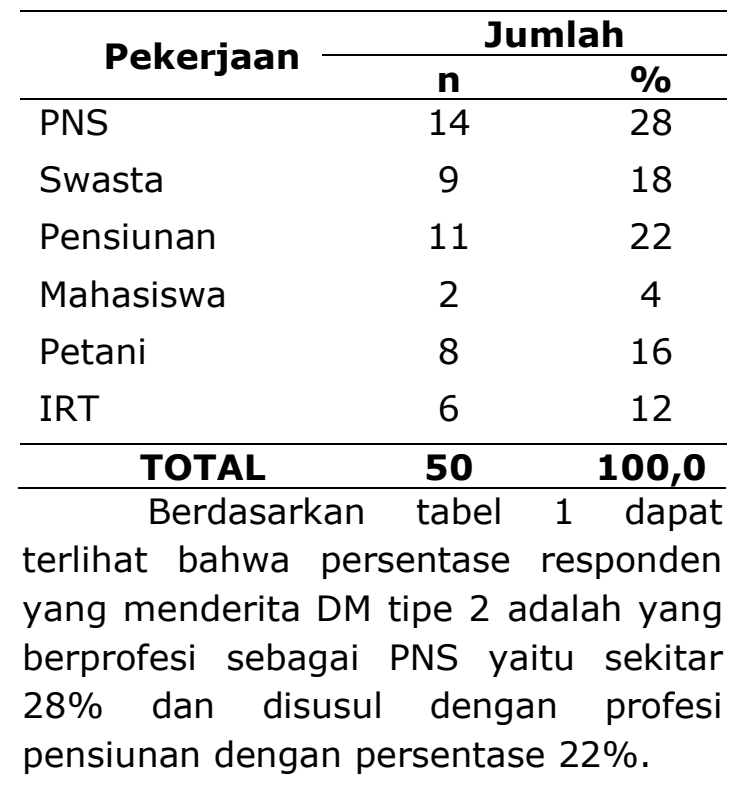

Tabel 2. Distribusi jenis kelamin responden DM tipe 2

\begin{tabular}{|c|c|c|}
\hline \multirow{2}{*}{$\begin{array}{c}\text { Jenis } \\
\text { Kelamin }\end{array}$} & \multicolumn{2}{|c|}{ Jumlah } \\
\hline & $\mathbf{n}$ & $\%$ \\
\hline Laki-laki & 28 & 56,7 \\
\hline Perempuan & 22 & 43,3 \\
\hline TOTAL & 50 & 100,0 \\
\hline
\end{tabular}

dilakukan dari 50 orang responden sebanyak $56.7 \%$ adalah laki-laki dan $43.3 \%$ adalah perempuan.

Tabel 3. Distribusi tingkat pendidikan responden DM tipe 2

\begin{tabular}{lcc}
\hline \multicolumn{1}{c}{ Tingkat } & \multicolumn{2}{c}{ Jumlah } \\
\cline { 2 - 3 } Pendidikan & N & \% \\
\hline Perguruan Tinggi & 6 & 12 \\
SMA & 11 & 22
\end{tabular}

\begin{tabular}{lcc} 
SMP & 17 & 34 \\
SD & 15 & 3 \\
Non Pendidikan & 1 & 0,2 \\
\hline \multicolumn{1}{r}{ TOTAL } & $\mathbf{5 0}$ & $\mathbf{1 0 0 , 0}$ \\
\hline
\end{tabular}

Tabel 3 diatas menjukkan bahwa tingkat pendidikan responden DM tipe 2 tertinggi persentase nya adalah SMP sebesar $34 \%$ dan disusul dengan SMA $22 \%$.

Tabel 4. Distribusi tingkat aktifitas fisik responden DM tipe 2

\begin{tabular}{lcc}
\hline \multicolumn{1}{c}{$\begin{array}{c}\text { Tingkat } \\
\text { Aktifitas } \\
\text { Fisik }\end{array}$} & \multicolumn{2}{c}{ Jumlah } \\
\cline { 2 - 3 } Tinggi & $\mathbf{n}$ & $\mathbf{\%}$ \\
Sedang & 13 & 26 \\
Rendah & 11 & 22 \\
\hline \multicolumn{1}{c}{ TOTAL } & 26 & 52 \\
\hline
\end{tabular}

Tabel 4 diatas terlihat bahwa angka kejadian penyakit DM tipe 2 terbesar pada responden yang memiliki tingkat aktifitas fisik rendah yaitu sebesar $52 \%$.

Tabel 5. Distribusi kelompok berat badan responden DM tipe 2

\begin{tabular}{|c|c|c|}
\hline \multirow{2}{*}{$\begin{array}{c}\text { Kelompok } \\
\text { Berat } \\
\text { Badan }\end{array}$} & \multicolumn{2}{|c|}{ Frekuensi } \\
\hline & $\mathbf{n}$ & $\%$ \\
\hline Obesitas & 18 & 36 \\
\hline Normal & 23 & 46 \\
\hline Kurang & 9 & 18 \\
\hline $\begin{array}{l}\text { TOTAL } \\
\text { Berdasark } \\
\text { diatas terlihat ba } \\
\text { kelompok bera } \\
\text { sekitar } 46 \% \\
\text { kelompok berat }\end{array}$ & $\begin{array}{l}\mathbf{5 0} \\
\text { hasil } \\
\text { espor } \\
\text { lan } \\
\text { disu } \\
\text { obes }\end{array}$ & $\begin{array}{c}\mathbf{1 0 0 , 0} \\
\text { penelitian } \\
\text { n dengan } \\
\text { mal ada } \\
\text { dengan } \\
36 \% .\end{array}$ \\
\hline \multicolumn{3}{|c|}{$\begin{array}{c}\text { Tabel } 6 \text {. Distribusi pola makan } \\
\text { responden DM tipe } 2\end{array}$} \\
\hline Pola & & lah \\
\hline Makan & $\mathbf{n}$ & $\%$ \\
\hline Tidak Sehat & 33 & 66 \\
\hline Sehat & 17 & 34 \\
\hline TOTAL & 50 & 100,0 \\
\hline
\end{tabular}


Ilustrasi pada tabel 6 diatas menunjukkan bahwa responden DM tipe 2 memiliki pola makan tidak sehat adalah sekitar $66 \%$ dan sehat $34 \%$.

Tabel 7. Distribusi tingkat merokok responden DM tipe 2

\begin{tabular}{lcc}
\hline \multicolumn{1}{c}{ Tingkat } & \multicolumn{2}{c}{ Jumlah } \\
\cline { 2 - 3 } \multicolumn{1}{c}{ merokok } & n & \% \\
\hline Berat & 13 & 26 \\
Sedang & 11 & 22 \\
Ringan & 6 & 12 \\
Tidak merokok & 20 & 40 \\
\hline \multicolumn{1}{c}{ TOTAL } & $\mathbf{5 0}$ & $\mathbf{1 0 0 , 0}$ \\
\hline \multicolumn{1}{c}{ Berdasarkan } & hasil & penelitian
\end{tabular}

pada tabel 7 diatas menunjukkan bahwa responden DM tipe 2 yang tidak merokok adalah persentase terbesar dengan persentase $40 \%$.

\section{Pembahasan}

Berdasarkan hasil penelitian yang telah dilakukan didapatkan data bahwa jumlah responden dengan jenis kelamin laki-laki lebih banyak dibandingkan dengan perempuan. Perbedaan persentase jumlah responden laki-laki dengan perempuan adalah $56,7 \%$ untuk laki-laki dan $43,3 \%$ untuk jumlah responden perempuan sesuai dengan tabel 2 .

Jenis pekerjaan responden pada tabel 1 dapat terlihat bahwa terdapat kemungkinan jenis pekerjaan dapat mempengaruhi tingkat kejadian sakit DM tipe 2 yang dialami oleh responden. Pada tabel tersebut terlihat bahwa pekerjaan sebagai PNS, pensiunan dan swasta menduduki posisi teratas sebagai penderita DM tipe 2. Hal ini terjadi diduga adanya jenis pekerjaan yang kurang bervariasi dan cenderung lebih banyak duduk dibandingkan bergerak. Hal ini juga dapat dilihat dari tingkat aktifitas fisik yang ada pada tabel 4.

Tabel 4 menunjukkan tingkat aktifitas fisik responden DM tipe 2 lebih dominan tingkat aktifitas fisik rendah dibandingkan tinggi dan sedang. Diketahui bahwa rekomendasi dari IDF (2019), bahwa aktifitas fisik merupakan salah satu hal yang perlu dalam menurunkan risiko dan juga mencegah terjadinya DM tipe 2. Hal ini dapat terjadi karena dengan adanya aktifitas fisik maka makanan yang dikonsumsi akan langsung diolah dan pergunakan oleh tubuh sen oleh responen bagai sumber energi. Sehingga tidak terjadi penimbunan lemak dan aliran glukosa didalam darah menjadi lancar. Hal ini sejalan dengan hasil penelitian yang dilakukan oleh (Rossen et al., 2015) dan (Trisnawati, 2013), aktifitas fisik akan dapat mempengaruhi terjadinya kegagalan pathogenesis dalam toleransi glukosa yang merupakan faktor utama penyebab DM tipe 2 serta dengan adanya latihan aerobic dapat menunda bahkan mencegah dan juga meningkatkan sensitifitas hormon insulin secara langsung.

Tabel 5 kelompok berat badan responden DM tipe 2, dari tabel tersebut dapat dilihat bahwa kelompok berat badan respnden yang mengalami obesitas atau kelebihan berat badan tidak terlalu tinggi atau masih lebih banyak jumlah responden yang berat badan normal. Hal ini menunjukkan kemungkian berat badan tidak terlalu berpengaruh terhadap angka kejadian DM tipe 2 dan perlu dilakukan penelitiian yang lebih spesifik dengan mempertimbangkan segala bentuk aktifitas fisik, pola makan, pekerjaan dan kejadian obesitas. Diketahui bahwa menurut IDF (2019), obesitas memang mempengaruhi tingkat kejadian dan linieritas penyakit DM tipe 2 . Namun hal yang perlu untuk dilihat adalah bagaimana pola makan dari pasien, aktifitas fisik berikut juga dengan kebiasaan merokok responden. Pada tabel 6 terlihat adanya pengelompokkan 
pola makan bagi reponden. Pola makan yang tidak sehat cenderung akan dapat mempengaruhi kejadian obesitas lebih utama dibandingkan dengan yang pola makan teratur dan sehat. Diduga angka obesitas yang tinggi dipenggaruhi oleh kebiasaan makan responden yang tidak sehat seperti yang dipaparkan pada tabel 5 dan disertai dengan rendahnya aktifitas fisik pada tabel 4 serta didukung dengan tingkat merokok responden pada tabel 7 . Merokok juga dapat meningkatkan risiko meningkatnya peluang dan menurunnya fungsi metabolism tubuh. Hal ini terjadi karena paparan terhadap asap rokok memiliki relasi yang kuat dengan kerusakan DNA yang dipicu oleh cekaman oksidatif (oxidative stress) dan karsinogenesis (Patel, et al., 2008). Meningkatnya radikal bebas didalam tubuh memiliki hubungan terjadinya penyakit degenerative seperti diabetes, kanker, dan jantung. Hal ini karena rokok berperan dalam memicu terjadinya kerusakan DNA dan basanya (8-oxoguanosine) (Lodovici \& Bigagli, 2009).

\section{KESIMPULAN}

Terdapat hubungan terjadinya penyakit diabetes melitus tipe 2 antara pasien yang melakukan aktfivitas fisik, berat badan, pola makan responden dan tingkat merokok responden. Risiko kejadian penyakit DM tipe 2 akan meningkat apabila beberapa faktor yang diukur tersebut saling mendukung.

\section{DAFTAR PUSTAKA}

Decroli. (2019). Diabetes Militus Tipe 2. Palembang. Pusat Penerbitan Bagian IImu

International Diabetes Federation [IDF]. (2013). IDF Diabetes Atlas. Ninth Edition. http://www.idf.org/diabetesatlas [20 Oktober 2014].

Lodovici, M., E. Bigagli. (2009). Biomarkers of induced active and passive smoking damage. International Journal of Environment Research and Public Health., 6: 874-888.

Patel, B.P., U.M. Rawal et al., (2008). Tobacco, antioxidant enzymes, oxidative stress, and genstic susceptibility in oral cancer. Am.J. Clin. Oncol, 31: 454-459.

Riset kesehatan dasar [RISKESDA]. (2019). Laporan Nasional Riskesdas. Jakarta.

Rossen J, et al. (2015). Physical activity promotion in the primary care setting in pre and type 2 diabetes. BMC Public Health. 15(647):1-11.

Simarmata, et al. (2020). Faktor-Faktor Yang Mempengaruhi Gangguan Tidur Pada Pasien Diabetes Melitus.

Trisnawati S K, Setyorogo 2. (2013). Faktor risiko kejadian diabetes melitus tipe II di Puskesmas Kecamatan Cengkareng Jakarta Barat Tahun 2012. Jurnal Ilmiah Kesehatan. 5(1) 